\title{
Judging the implementation of Green Accounting: Case study at PT. PLN (Persero) UPK Bukittinggi
}

\author{
Zalida Afni ${ }^{1}$, Reno Fithri Meuthia ${ }^{2}$, Zahara $^{3}$, Rezkia Rahmayani ${ }^{4}$ \\ \{zalida.afni@yahoo.com,enofm87@gmail.com,rezkiahtp@gmail.com
}

State Polytechnic of Padang, Accounting Department, Limau Manis Padang ${ }^{1-3}$

\begin{abstract}
This research aims to describe the implementation of Green accounting in PT PLN (Persero) of
Bukittinggi UPK, using four progressive stages of environmental awarness , environmental Involvement, Environmental reporting, and environmental audititng were based on the study of teoh and Thong (1984)[1]. The research also describes the policy of limited liability company to encourage companies to carry out social responsibility and corporate environment. This research is a qualitatively descriptive study with case study methods. Data is obtained by interview techniques and documentation. The results of this research show that PT PLN (Persero) UPK Bukittinggi has awareness to carry out social and environmental responsibility. The implementation of social responsibility and the environment of his company is known as CSR. Policies governing limited liability company are able to encourage the involvement of PT PLN (Persero) UPK Bukittinggi towards social responsibility. The activities of PLTA that are shaded by PT PLN (Persero) UPK Bukittinggi and CSR activities are deemed to have contributed to the policy of environmentally friendly industries.
\end{abstract}

Keywords: Green Accounting, Environmental, CSR

\section{Introduction}

Since the term global warming, every country strives to mitigate the various threats posed by environmental issues. Global and national ecological crises caused by environmental damage due to natural resource exploitation and the environment are increasingly severe and alarming. The crisis has caused various environmental disasters that are very harmful and threaten the continuity of human life. It is one of the motivating aspects of green accounting. Green Accounting is an accounting process that integrates the recognition, value measurement, recording, summarize, and reporting of financial, social and environmental information in a unified, accounting reporting package, which is useful for Assessment and decision making of economic and non-economic decisions. Accounting reports not only present financial information but also integrated social and environmental information. The purpose of green accounting is to try to reduce the negative effects of economic activities and systems on the environment. In Indonesia, environmental accounting has difficulty measuring the value of costs 
and benefits arising from industrial processes. Reporting on social performance as well as environmental performance is not contained in the conventional financial statements in detail, in conventional financial statements only economic performance is easily found (Idris, 2012) [2]. Dewi (2016) [3] researched green accounting among SMES, the constraints faced by SMES because there is no strict policy for SMES, but for the limited liability company This policy has been set in detail. The aim of the research is to answer some problems, namely to see if PT PLN (Persero) UPK Bukittinggi has awareness, implement, report, and examine activities related to social responsibility and corporate environment. This research also wants to know whether the existence of green accounting related policies in Indonesia can encourage the implementation of green Accounting in PT PLN (Persero) UPK Bukittinggi as one of the state-owned enterprises, and want to see as far as where PT PLN (Persero) UPK Bukittinggi is also involved in the policy of environmentally friendly industry. This research is expected to contribute scholarly contributions to the development of green accounting Studies in Indonesia. For PT PLN (Persero) UPK Bukittingi expected that the research can contribute as a material to enter for management in the company's operations to implement green accounting and to make the company as an environmentally friendly industry. For the contribution of the policy, this research is expected to assist the Ministry of BUMN as a regulator of state-owned enterprises in Indonesia to formulate green accounting policy and supervise the operational path State-owned enterprises in Indonesia.

\section{Methodology}

This research is done through a qualitative approach. This approach was chosen due to a thorough understanding of the company's green accounting implementation, and allows the authors to see the practice and understand and describe how the entity's conception of Awareness, involvement, reporting and green accounting checks. In addition, qualitative research also provides opportunities to be able to describe directly how green accounting practices have been implemented during this time. This research uses case study design. In the business world, case studies use empirical evidence of one or more organisations as an effort to study in the context of learning, using multiple sources of evidence, even though the majority of the evidence comes from Interviews and documents.

The author chooses PT PLN (Persero) UPK Bukittinggi, West Sumatera, as a case in this research because PT PLN (Persero) is one of the state-owned enterprises whose operational activities directly related to natural resources, from the start The generation, distribution, products, and services to the public by PT PLN (Persero).

BUMN has its own ministry in the unitary Republic of Indonesia, with all existing legal bases to apply green accounting, state-owned enterprises are further tightened by the regulations issued by the Ministry of State-owned enterprises, so it is expected that the implementation of green accounting can run as well as possible in PT PLN (Persero) UPK Bukittinggi.

To focus the research results, the authors limit the scope of research to be implemented to know the implementation of green Accounting in PT PLN (Persero) UPK Bukittinggi which is seen based on the progressive stages discussed Teoh and Thong (1984). With the regulation governing state-owned enterprises and limited liability, whether it affects the implementation of green Accounting in PT PLN (Persero) UPK Bukittinggi.

In this study, authors collected two types of data, namely primary data and secondary data. Primary data collection, authors perform several techniques in collecting data such as in-depth interviews with management, whether in application, reporting, or inspection. The author interviewed several parties who understand the problem of research and influential in decision making in PT PLN (Persero) UPK Bukittinggi, namely CSR team. In conducting authors ' interviews using semi-structured interviews so that respondents could share their opinions and ideas regarding the proposed questions and allow the open-ended question when there are some new points Appears from the interview answer. All authors ' interview activities record the transcript writers to get concrete evidence.

For secondary data, the authors get from a review of documents related to implementation and reporting of green accounting as well as some other documents. The authors also dig information with the study of libraries of books, articles, and websites of PT PLN (Persero) related green accounting. The 
program feasibility Assessment and PT PLN (Persero) UPK of Bukittinggi CSR Report for the year 2018 become a secondary source of data in this research.

Thematic analysis is a method that authors will do in analyzing the data in this study. Thematic analysis is a way of identifying themes that are patterned in a phenomenon. The process of coding information that could result in a list of themes, theme models, or complex indicators, qualifications usually related to that theme, or things between or a combination of those mentioned. These themes allow interpretation of the phenomenon. A theme can be identified at a manifest level, which is directly visible. A theme can also be found at the latent level (latents level), not explicitly visible but underlying or overshadow (underlying the phenomena) (Poerwandi, 2005) [4].

According to Hayes (in Indrayanti et al, 2008)[5]. The thematic analysis process is, the information is sorted by theme number. The theme in this regard refers to ideas and topics acquired in material analysis and generates more than one data group. The same theme is described by different words, found in different contexts, or expressed by different people. The phases of the thematic analysis of Hayes (in Indrayanti et al, 2008) are as follows:

1. Set up data to be analyzed by grouping

2. Identifying specific items relevant to a study topic

3. Sort data by theme similarity

4. Test theme similarities and formulate in a specific category

5. Pay attention to each theme separately and carefully to re-test each transcript of the answer that has the same theme

6. Use all material related to each theme to create a final theme containing a category name and its understanding along with supporting data, and select the relevant data to be made into illustrations and report Each theme. 


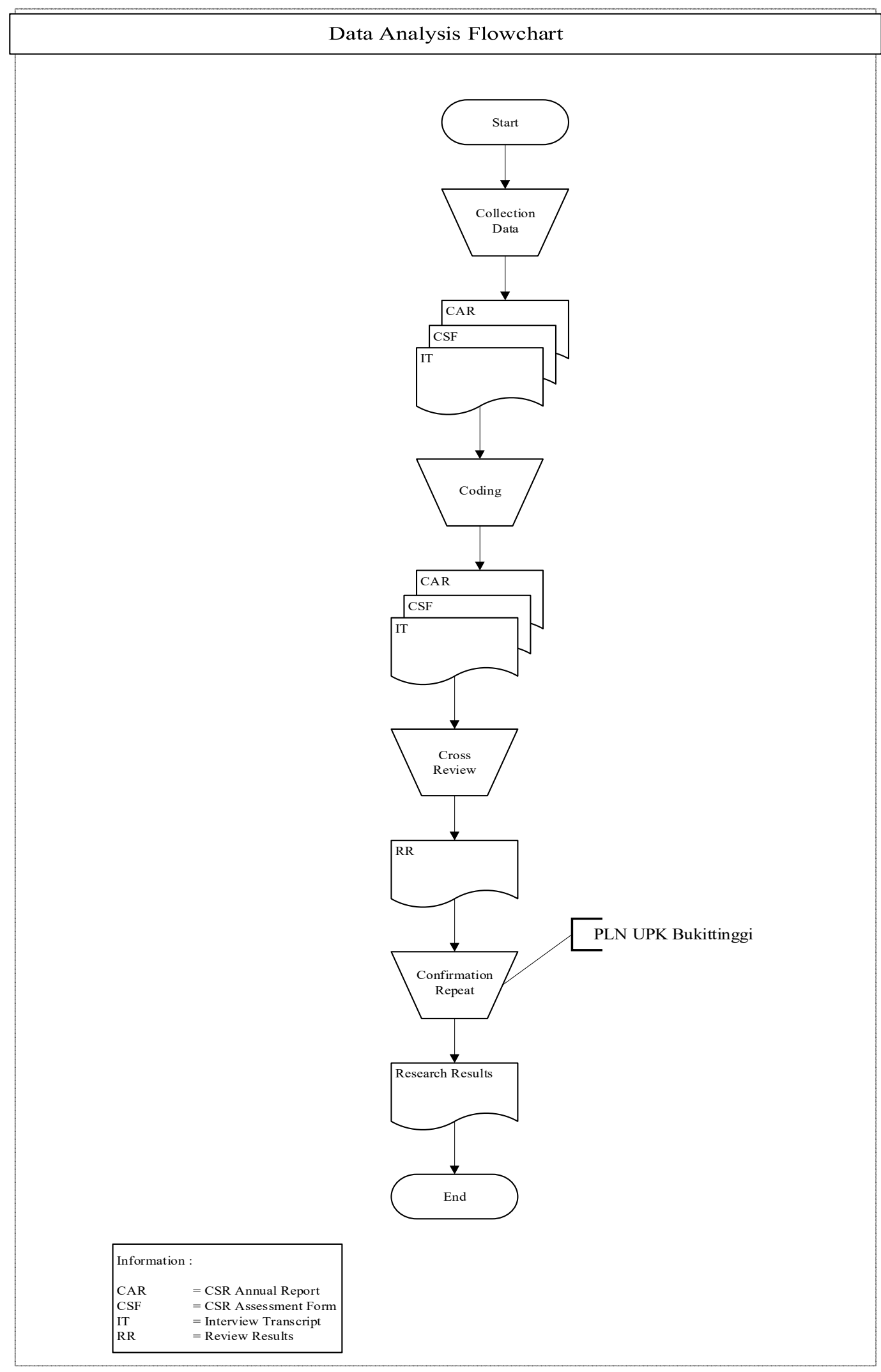

Fig 1. Data Analysis Flowchart

(created by Rezkia Rahmayani, with the explanation according to Hayes in Indrayanti et al, 2008) 
This research is done to illustrate how the implementation of green accounting in one of the companies whose operational activities are very close to the environment. First, the authors will see how the implementation of green accounting based on progressive stages discussed Teoh and Thong (1984), namely environmental awarness, environmental involvement, environmental reporting, environmental audit.

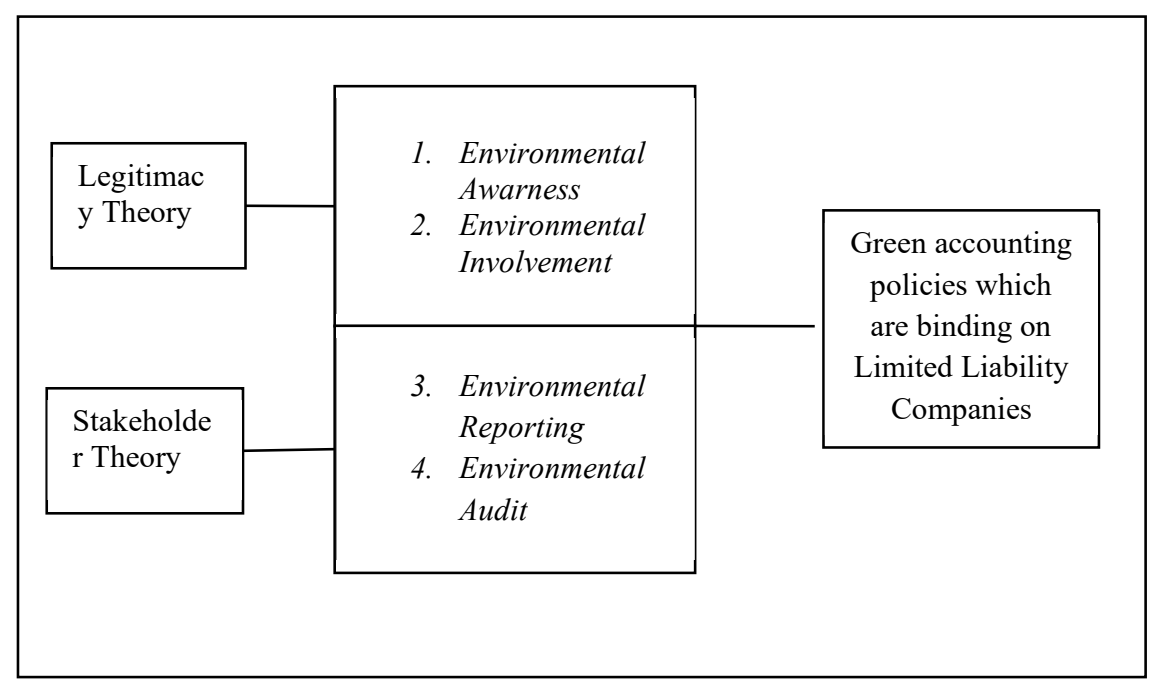

Fig 2. Framework Research

Then, this study will see if the policies binding to the limited liability company encourages PT PLN (Persero) to apply green accounting. If the policies related to green accounting in Indonesia is able to encourage environmental accountability in PT PLN (Persero), then the authors will be seen as far as the role of PT PLN (Persero) as a state-owned enterprises in the friendly industry of the House.

\section{Result and Discussion}

\subsection{Environmental Awarness PT PLN (Persero) UPK Bukittinggi}

PT PLN (Persero) UPK Bukittinggi is very aware of the importance of awareness on society and environment. CSR implementation is expected to provide reciprocal effect between PLN and the community. PLN has a full community of support, and the public can feel the presence of PLN's concern in the community.

"Terkait dengan PLN terhadap lingkungannya, PLN sangat peduli dengan lingkungan, bahkan sadar dengan adanya PLN disetiap kawasan masing-masing, karena PLN itu pelayan masyarakat, jadi masyarakat jangan semena-mena terhadap PLN, (...) jadi dengan adanya CSR itu lahirlah kebaikan antara kedua belah pihak. kita membantu itu kita upayakan bagaimana umpan balik dari masyarakatnya..."

(Mr. Koji, 3 September 2019)

The theory of legitimacy asserts that the company continues to strive to ensure that they operate within the frame and norms of the society or environment in which the company resides, where they strive to ensure that their activities ( Accepted by outside parties as legitimate (Deegan, 2004) [6].

PLN realizes that as a company with the only market capitalization in Indonesia that is located around the community, PLN wants to help a lot not only the products of PLN which are the main needs of the community, but PLN's CSR presence can also be Welfare of the surrounding communities.

"sebenarnya itu bentuk partisipasi perusahaan ya karena perusahaan besar yang ada di suatu tempat jadi perusahaan ini ingin mensejahterakan juga masyarakat disekitar yang berdampak langsung sama perusahaan itu. Kan intinya dia sosial jadi membantulah. (...) Dengan adanya perusahaan disana adanya program berkesinambungan pemberdayaan mereka bisa nambah lapangan kerja." 
(Mr. Eko, 3 September 2019)

\subsection{Environmental Involvement, Environmental Reporting, and Environmental Auditing at PT PLN (Persero) UPK Bukittinggi}

PT PLN (Persero) UPK Bukittinggi has a team that is responsible for the course of CSR activities. This team is to arrange for CSR activities to run according to the plan in UPK Bukittinggi. The CSR team is tasked with planning CSR implementation, field survey, drafting CSR budget, performing CSR realization, and report on CSR realization. Therefore, when the audit is conducted for CSR activities, the CSR team is in turn responsible to the audit team.

"Dan dalam CSR itukan ada diklat CSRnya. Bahkan dia ada sertifikat CSRnya. Yang penting dalam memilih tim orang itu ada bersertifikat. Dan yang lain jika tidak memiliki sertifikat, yang lain itu kita melihat dari sisi orangnya. Jika orangnya baik, ramah, tanggap, dan peduli. Itu kan berarti sudah ada didalam lingkup orang yang kita pilih dan kita jadikan tim. (...) Kalau dia kemampuannya di lingkungan sudah pasti kita ikutkan dia."

(Mr. Koji, 3 September 2019)

Requirements incorporated into the team also have certain qualifications. The people who belong to this team have already obtained a CSR certification from the head office and get many trainings related to the social responsibility of the environment and society. For team members who are not yet certified, member selection is done by looking at the personal criteria, such as having a high social spirit, caring for the environment, etc.

CSR Program at PT PLN (Persero) UPK Bukittinggi is reported in the implementation of CSR. The contents of the report are letter of introduction from UPK Manager, treatise results Survey, documentation, news events, and receipts. All costs incurred in CSR in the realization process of CSR are reported as expenses outside of business. Each program type, has different account names in the income statement.

"Kita CSR itu termasuk ke beban, masuknya ke beban di luar usaha, bukan beban operasional, tetapi kan akan tetap mengurangi laba rugi..."

“...kenapa tidak dijadikan investasi, karena otomatis diakan nggk menambah aset, kalau di PLN kan kalau dia salah satu kriteria kalau dia dijadikan investasi salah satuya otomatis bukan harus yaa, misalnya kita ini di PLN ada dua anggaran operasional dan anggaran investasi, anggaran investasi ini biasanya akan menjadi aset tapi tidak semua bisa menjadi aset, ada unsur-unsurnya, ada kriteria-kriterianya, kriteria-kriteria ini ditentukan oleh SK Direksi"

(Mrs. Wita, 2 September 2019)

According to Andreas Lako (2018) [7], the accounting treatment of environmental and community social responsibility costs can be recognized as a socio-environmental invesment because it is believed to have a definite economic benefit in the future. PT PLN (Persero) UPK Bukittinggi has a reason to acknowledge CSR activities as a burden because of the recognition of the addition of assets in PT PLN (Persero) has the criteria set by the DECREE of the board of Directors. The things listed on the investment budget of PT PLN (Persero) UPK Bukittinggi usually that will be the addition of assets in PLN.

At the end of the year, reports of all CSR activities within a year were collected and divided into one. Annual CSR Realization Report is delivered to the Sumbagsel generation parent Unit. UIP of the Sumbagsel that will reappear all reports of CSR realization of existing units under it, and reported to the head office of PT PLN (Persero).

The theory of stakeholders describing the company should maintain a relationship with its stakeholders by accommodating the wishes and needs of its stakeholders, especially the stakeholders who have power over the availability of resources used to Operational activities of the company, e.g. Labor, market over the company's products and others (Chariri and Ghozali, 2007) [8]. By reporting the company's environmental social responsibility activities, PT PLN (Persero) UPK Bukittinggi accommodates stakeholders in the needs of the realized responsibility information. 
At PT PLN (Persero) UPK Bukittinggi, there are two types of auditing, the first internal audit, and the second is external audit. During this time, CSR activities are examined in depth at the Internal Audit. Not only the nominal amount of CSR funds checked, but the evidence in the field also became an examination material. Internal audit of the work started during quarter IV conducted by Internal Audit team.

"Terkait dengan CSR dia langsung mengaudit yang bersangutan yaitu pengelolaannya siapa ketua timnya. Nanti itu kan pelaporannya sudah ada, jadi yang perlu ditanyakan itu si penanggung jawabnya saja"

"Misalnya orang yang audit pengen lihat kelapangan, ya kita ajak ke lapangan. Apa benar kita membantu masyarakat itu atau tidak. Bukan audit diatas meja saja"

(Pak Koji, 3 September 2019)

For external audit, there has been no external audit on CSR activities at UPK Bukittinggi. Auditor examines the Sumbagsel generation Unit which becomes the parent of UPK Bukittinggi, so if the account of CSR burden is one of the audit sample in the Sumbagsel power Unit, then the UPK CSR team in Bukittinggi prepares the documents necessary during the inspection process.

"Kalau auditor dari BPK biasanya cuma ngambil sampel, dan jarang juga akun [beban] CSR yang dijadikan sampel, kalau diminta waktu audit kantor induk, ya berkasnya kita siapin, kita kirim ke kantor induk."

(Mrs. Wita, 2 September 2019)

\subsection{Policy related to limited liability company that encourages PT PLN (Persero) UPK Bukittinggi to apply Green Accounting}

Many limited liability company policies governing environmental concern. The law on which the legal basis of PT PLN (Persero) conducts CSR is Law No. 40 year 2007 about the limited liability company. This law governs the company carrying out its business activities in the field of and/or relating to natural resources obliged to carry out social and environmental responsibilities. UPK Bukittinggi as a sector responsible for the performance of HYDROPOWER that utilizes water as SDA to spin the turbine.

"Untuk melakukan CSR sudah diatur Undang-Undangnya di peraturan pemerintah yang itu menjadi kewajiban setiap perusahaan untuk membagikan labanya untuk ke masyarakat sekitar situ. Kalau kita disini mengikuti aturan dari PLN pusat kita hanya menghusulkan programnya untuk 3 unit yang mana Singkarak, Maninjau, sama Batang Agam."

(Pak Eko, 3 September 2019)

The Ministry of State Enterprises also publishes regulations relating to environmental and community social responsibility activities, namely MENEG regulation of State-owned enterprises number PER-05/MBU/2007 concerning the Partnership Program of state-owned enterprises with small business and Community Development Program. This policy governs that state-owned enterprises are obliged to conduct partnership and community Development Program (PKBL) by 4\%, with each 2\% for the partnership Program and 2\% for environment development Program. Other regulations of the head office of PT PLN (Persero) are SOP PKBL and P3L number SKDIR No. 366/DIR/2007 regarding the scope of the CSR implementation program. 


\subsection{The role of PT PLN (UPK) Bukittinggi in environmentally friendly industries}

PT PLN (Persero) UPK Bukittinggi is directly manage three hydroelectric power plants. The water is used only to spin the turbine that will produce electricity. Turbine playback activities do not produce any waste in any form.

PT PLN (Persero) UPK Bukittinggi is also very concerned about the movement of environmentally friendly industries and sustainable development. Not only seen from the activity of PLTA that does not produce waste, but the water used to spin the power plant turbine will flow to the community farmland.

"kalau kita melihat dari sisi pembangkit di UPK Bukittinggi adalah ramah lingkungan, karna sumber-sumber air mereka berasal dari tanah jadikan tidak akan ada zat kimianya"

"tidak ada [limbah] yang dihasilkan oleh aktivitas [PLTA], jika ada itu baru namanya kita mencemarkan lingkungan. Karna dia masuk air keluar juga air.

"kalau air keluaranya itu bahkan sangat dibuutuhkan oleh masyarakat, contohnya, yang terkait dengan PLTA Singkarak. PLTA Singkarak itu di daerah Pariaman, Pariaman itukan airnya kecil dan tidak memadai untuk mengaliri pertanian masyarakat di daerah Padang Pariaman. Dengan adanya sumber air yang kita alirkan dari Danau Singkarak menuju Padang Pariaman itu mudah perekonomian masyarakat membaik dalam sektor pertanian"

(Pak Koji, 3 September 2019)

In Bank Indonesia regulation No. 7/2/PBI/2005 on the determination of asset quality rating for commercial banks. The rules of environmental aspects become one of the terms in lending. Any company that wants to get banking credit, should be able to show its concern on environmental management. Standard measurement of waste quality company used is PROPER. By using five ratings (black, red, blue, green, and gold) The study will be ranked based on success in the management of their waste.

Implementation of operational activities and CSR program of PT PLN (Persero) UPK Bukittinggi also aims to pursue and maintain the company's performance rating Program in Environmental management (PROPER). Therefore, PLN always seeks its operational activities to be involved in environmentally friendly industry policies.

\section{Conclusion}

The results showed that the implementation of green accounting has not been implemented completely, but some aspects in the implementation phase is already conducted by PT PLN (Persero) UPK Bukittinggi. Here are some summaries of this study:

a. In the implementation of environmental social responsibility and community of PT PLN (Persero) UPK Bukittinggi has had awareness to carry out social responsibility of the environment and society called CSR terms.

b. PT PLN (Persero) UPK Bukittinggi has been implementing, reporting, and conducting inspections regarding environmental and community social responsibility activities. However, in reporting on the activities of the responsibility, PT PLN (Persero) UPK Bukittinggi recognizes as a burden outside the business and reduces the company's return on the income statement.

c. The company's limited policy in Indonesia is capable of encouraging the State electricity company to carry out social responsibility for the environment and society. The Ministry of SOES as an institution that supervises the performance of the state owned enterprises also publishes policies that encourage PT PLN (Persero) UPK Bukittinggi to perform environmental and social responsibility of society.

d. The operational activity of PT PLN (Perseo) UPK Bukittinggi does not produce waste, does not pollute water for HYDROPOWER, and environmental and community social responsibility activities are deemed to contribute to the policy of environmentally friendly industries. 


\section{References}

[1] H. Y. Teoh and G. Thong, "Another look at corporate social responsibility and reporting: An empirical study in a developing country," Accounting, Organ. Soc., vol. 9, no. 2, pp. 189-206, 1984.

[2] Idris, "Akuntansi lingkungan sebagai instrumen pengungkapan tanggung jawab perusahaan terhadap lingkungan di era green market," Eco-entrepeneursh. Semin. Call Pap. "Improving Perform. by Improv. Environ., 2012.

[3] S. R. Dewi, "Pemahaman Dan Kepedulian Penerapan Green Accounting : Studi Kasus Ukm Tahu Di Sidoarjo Understanding and Application of Green Accounting Awareness : a Tofu Sme Case Study in Sidoarjo," Ekon. Bisnis, pp. 497-511, 2015.

[4] E. K. Poerwandari, "Pendekatan Kualitatif: Penelitian Perilaku Manusia," Depok Lemb. Pengemb. Sarana Pengukuran dan Pendidik. Psikol. (LPSP3), Fak. Psikol. UI, 2007.

[5] Indrayanti, K. W. Yuniarti, I. Rekso, Adiwibowo, and U. Kim, "Bagaimana Laki-laki dan Perempuan Percaya (Trust) pada Orang Asing? Sebuah Study Psikologi Indegenus." Center for Indigenous and Cultural Psychology, Yogyakarta, 2008.

[6] C. Deegan, Financial Accounting The, 4th ed. McGrsw-Hill Education (Australia) Pty Ltd, 2014.

[7] A. Lako, Akuntansi Hijau. Jakarta: Salemba Empat, 2018.

[8] A. Chairiri, "Teori Akuntansi," Univ. Diponegoro, 2007. 